\title{
A DEIXIS ANALYSIS OF SONG LYRICS IN BACK TO YOU BY SELENA GOMES
}

Arini Hidayah

Faculty of Language and Literature, University of Surakarta. arinihidayah@unsa.ac.id

\begin{abstract}
The objectives of this study are to identify the kinds of deixis that are used in the song lyrics Back To You, to find out the dominant types of deixis that are used in the song lyrics Back To You. This research belongs to qualitative research. The researcher uses observation method, while the data collection techniques is listening and analyzing the songs of "Back to you" by Selena Gomez. The result of this research is the song lyrics of Back To You use all types of deixis. Person deixis almost occurs in every lyric of Back To You. There are 45 data of person deixis consisting of first, second and third person deixis. In addition, the other types such as time deixis (2 data) and place deixis (1 datum) also occur in a song of Back To You. Most of personal deixis in Back To You song lyric refer to the speaker itself which are encoded by first singular person deixis like $I$ and $M y$. While for first plural person deixis which are We mostly refer to the speaker.
\end{abstract}

Keywords: Deixis, Song, and Lyric.

\begin{abstract}
ABSTRAK
Tujuan dari penelitian ini adalah mengidentifikasi tipe deiksis dan menemukan tipe dominan deiksis dalam lirik lagu Back To You dari Selana Gomez. Penelitian ini termasuk jenis penelitian kualitatif. Penelitian ini menggunakan metode observasi. Teknik pengumpulan data dengan cara mendengarkan lagu dan mengananalisis lagu Back To You dari Selana Gomez. Hasil dari penelitian ini yaitu semua tipe deiksis ditemukan dalam orang (45 data), tempat (1 data), waktu (2 data) deiksis ditemukan dalam lirik lagu Back To You dari Selana Gomez. Deiksis orang sering ditemukan di lirik Back To You. Kebanyakan tipe deiksis yag ditemukan dari penelitian ini yaitu deiksis orang seperti $I$ dan $M y$. Sedangkan deiksis jamak orang yang banyak ditemukan yaitu We yang ditujukan kepada pendengar.
\end{abstract}

Kata Kunci: Deiksis, Lagu, danLirik. 


\section{INTRODUCTION}

Language is a tool or system of symbols designed for purpose of communication and interaction with each other (Lyons, 2002). In addition, people use language to transmit and express their ideas, emotions or desire either in oral or written forms. Therefore, the language that we used ought to be meaningful to prevent misunderstanding or misinterpretation between sender and receiver. Furthermore, language is not only used as communication media but also usually involved in other fields such as language and arts. It can be found in advertisement and entertainment which appear in society such as music, novel, film or movie.

One example of entertainment media is music which is familiar in society. Music is a basic of human instinct, and also a daily basis human activity which is universally inspired with love and experience (Piragasam et.al, 2013). It is universal among human cultures. Music is expected to give pleasure for people listening to it that is an arrangement of sounds made by musical instruments, singing or computers, or a combination of these (Walter, 2008).

Music is a basic instinct of human being, a daily basis human activity which is universally engaged with, loved and experienced. Music plays an important role in the formation of a person's identity. Previous researches have revealed substantial findings on how music is vital in human's biological and history; not only that music equipped the process and ability to experience music (Levitin in Piragasam, dkk: 2013), but music was also used to prolong human being's life (Dissanayakein Piragasam, dkk: 2013). In addition a number of lyrics in song also give an inspiration for life. Therefore, when the people listen to song lyric, sometimes they do not only try to apprehend the meaning of lyric itself, but also the meaning of the reader or speaker means. The study of what speakers mean or speaker meaning is called pragmatics.

Yule (1996:3) claimed, pragmatics is concerned with the study of meaning as communicated by the speaker (or writer) and interpreted by listener (or reader). Communication recognizes the meaning of words and speakers mean in utterance or sentence. Sometimes misunderstanding of meaning could happen in the language users. That understanding related to reference of the utterance or sentence. In order to understand about a reference of utterance, reader or listeners should be able to identify the contexts of utterance.

Deixis is one of the most basic things in technical term of utterances (Yule, 1996). The word 'deixis' is borrowed from the Greek word for pointing or indicating. Additionally Levinson (1983: 55) advanced, deixis directly concerns with the relationship language and context which is reflected in structures of language theirselves.

This research focuses on the study in song lyrics especially in Selena Gomez album because it will be more interesting if we study about something which becomes too close to part of human life such as music. Basically, song lyrics could be said as a part of discourse. Moreover, the researcher assumes that many deixis words 
Vol.2. No.2 AUGUST 2019

and also their meaning could be found in the song lyrics of Back to you by Selena Gomes. In fact the listeners sometimes still get difficulty to determine the exact meanings of deixis that are used in this English song. Thus, study about exact meaning of deixis in song lyrics becomes crucial andinteresting.

In this study, the researcher wants to analyze deixis in song lyrics of Back to you by Selena Gomes, not only because it has deictic words but also many people especially teenagers are interested in this album. From those reasons the researcher decided to create a research entitled 'A Deixis Analysis of Song Lyric In Back To You By Selena Gomes'. The researcher hopes that it can help the listeners easily to understand the use and the meaning of deixis, especially in song lyric.

The aims of the research are to identify the kinds of deixis that are used in the song lyrics in Back to you and to find out the dominant types of deixis that are used in the song lyrics in Back to you. The focus of this study is to investigate deixis in the song lyrics of Back to you using pragmatic approach. The song which was released in Mei, $10^{\text {th }} 2018$ is chosen as the subject of this study and used as data.

There are many definitions of pragmatics. It comes from some linguists. Every linguist has his own concept and principal about pragmatics itself. Pragmatics is a part of linguistics which is about communicating meaning in context. It concerns with meaning (Kreidler, 1998). According to Cruse (2006), Pragmatics is study about aspects of meaning which are dependent on context. Griffith (2006: 1) also argued that pragmatics is concerned with the use of tools in meaningful communication.

There are some proposed definitions for pragmatics (Potts: 2004). Pragmatics has as its topic those aspects of the meaning of utterances with cannot be accounted for by straightforward reference to the truth conditions of the sentences uttered (Gazdar, 1979:2). It has to do with language use, and with going beyond the literal meaning (Kadmon, 2001:3). In addition, Pragmatics studies the use of language in context, and the context dependence of several of linguistic interpretation (Lycan, 1995:588).

Pragmatics is the study of those context-dependent aspects of meaningwhich are systematically abstracted away from in the construction of contentor logical form (Horn and Ward. 2006: 7). While according to Parker in Wijaya and Rohmadi (2011: 4) said that pragmatics is distinct from grammar, which is the study of the internal structure of language.In short, they said that pragmatics is the study of what speakers mean or speaker meaning. In communication, people have to recognize the meaning of words in utterance and also what speakers or writers mean by their utterance to be able to communicate clearly. Pragmatics is the study of contextual meaning. It is about how the speakers manage what they want to say in obedience with who they are talking to, where and when the utterance is uttered. Involving the interpretation of what people mean in a particular context and how the context influences what is said is an essential component in this study. Third, pragmatics is the study of how more gets communicated than is said. The study explores how a great deal of what is unsaid is known as part of what is communicated. It shows that how listeners can make

\section{Surakarta English and Literature Journal}


Vol.2. No.2 AUGUST 2019

inferences about what is said in order to arrive at an interpretation of the speaker's intended meaning.

There are many linguists giving different definitions of deixis, such as Yule (1996: 9) stated that deixis is derived from Greek words that means "pointing language". Similarly with Saeed (2003: 182), he stated that deixis as a technical term from Greek "deiknymi" to show or to point out things. Yule (1995:9) stated that deixis is a technical term for one of the most basic thing we do with utterances, some linguists also called deixis as indexical. As well as, Lyons (1997: 637) stated that deixis is the location, identification of people, objects, events, process, and activities which is being talked about or referred to, in relation to the time, when the speakers says the utterance, or when the hearer hears it. In addition Levinson (1983:54) stated that, deixis refers to the phenomenom where in understanding the meaning of certain words and phrase in an utterance requires contextual information. Words or phrases that require contextual information to convey meaning are deixtic.It means, deixis is used to refer ourselves to other and object in speaker and listener environment, to locate actions in a time frame relative to the present, used to locate parts of text in relation to other parts, and it also to show social relationship the social location individuals in relation to others (Hatch, 1992:210).

\section{Person Deixis}

Person deixis is pronoun to point people. Saeed ( $1997: 192$ ) stated that person deixis is deixis with the role of participants in the conversation, such as speaker, spoken, and addressed. According Cruse (2006:127), person deixis is divided into 3 parts. They are first person, second person, and third person deixis.

\section{Place Deixis}

Place deixis is also described as spatial deixis, where the relative location of people and things is being indicated. Place deixis or spatial deixis usually expressed in this, these, there, here, that, and those. Place deixis concerns the encoding of spatial locations relative to the location of the participants in the speech. (Levinson, 1983:62). Levinson stated that place or space deixis concerns for the specification of locations to anchorage points in the speech event and typically the speaker, and there are two basic ways of referring objects by describing or naming them on the one hand and by locating them on the other.

\section{Time Deixis}

Time deixis is also called as temporal deixis. Levinson said that the basis for systems of reckoning and measuring time in most languages seem to be the natural and prominent cycles of day and night, lunar months, season and years. Time deixis makes ultimate reference to participant-role, so it is important to distinguish the moment of utterance from the moment of reception (Levinson, 1983:73). Every sentence makes reference to an event time. Time can only be determined in relation to the time of the utterance.

The researcher wants to present the previous researches that deal especially with Deixis Analysis. The previous research was done by Hasanah, (UMS, 2006)

\section{Surakarta English and Literature Journal}


Vol.2. No.2 AUGUST 2019

entitled The Use of Deixis in Gladiator Movie's Manuscript. The results of this research are to find deixis devices and clarify the meaning of deixis devices that be used in movie's manuscript. The researcher uses movie's manuscript as the data and clarifies deixis devices based on pragmatics meaning.

The second previous study on this research is a study about the use of deictic expression and had been conducted by Sari Wulandari (UNDIP, 2008) entitled "The Use of Deictic Expression at Early Pre-Operational Stage Children. In her thesis, she analyzed the use of deictic expression by two sisters (siblings) at early pre-operational stage and not only analyzed the use of person deixis but also time and spatial deixis. In addition, she connected her research with the context, reference, and cognitive development in children. The side that differentiates this research to her is that this research concerns about the use of politeness and also social factors as the communication strategy behind certain use of person deixis by the university students, not the children.

After all, the researcher makes conclusions that the differences among this research with the previous researchs above are this research used lyric song Back to you by Selena Gomez as object of the research and his research also tries to analyze the meaning and the function of person deixis in lyric song Back to you by Selena Gomez using Pragmatics approach.

\section{METHODOLOGY}

This is a research uses a descriptive qualitative methodology, because the data in this research are lyrics in the song. Descriptive qualitative is the method of research used to describe nature phenomenon happened and relevancies between one phenomenon and the others. The research does not use any statistical procedure so that the researcher will describe the data obtained to answer the research questions. This research uses descriptive qualitative research because the data of the research is words or utterance and it will be analyzed by explaining the data descriptively.

Santosa (2012:42) states that data is object of research or the reality that is made the focus of research. Furthermore, it is stated that there are two types of data. They are primary data and secondary data. Primary data is data that is collected by a researcher directly from the field of research and secondary data is data which is collected by other researcher and is used by a researcher to support his research. (Blaxter et al., 2006: 153).

The data source of this research is song lyrics Back to youby Selena Gomez. Which contains person deixis that is categorized into 3 types.Data collection is gathering process of information from relevant source purposing to answer the research question. This research uses documented and library method to collect data. Library method is knowledge about resources that is used in research, or document which used to find data variable in form of note, transcriptbook, magazine, picture and data. Whereas, documentation method is collecting data through books,

\section{Surakarta English and Literature Journal}


Vol.2. No.2 AUGUST 2019

newspaper, artistic words, memorabilia, biography, etc. Researcher collects data by doing steps, as follow:first, the researcher listened to the songs of Back to you by Selena Gomez in order to understand the lyrics in detail. Second, the researcher searched the script of the lyrics of Back to you by Selena Gomez on internet. Third, the researcher choses the lyrics to be analyzed from the song of Back to youby Selena Gomez. Fourth, the researcher marked all of the chosen lyrics to be analyzed.

After collecting the data from the script of lyrics, the researcher analyzed the data as follows: First, the researcher determined some words expressions that include in deictic expressions. Second, the researcher classified the deictic expressions that have been determined based on their criteria. Third, the researcher analyzed the types of deixis, namely: person deixis, time deixis, and place deixis.

\section{FINDING AND DISCUSSION}

The researcher found that the lyrics tend to use such types of deixis include person deixis, time deixis, and place deixis in Back to you song lyrics. The types of deixis used are various and have different references and meanings.

This research finds thatnperson deixis, time deixis, andplacedeixis occur in songs of in Back to younsong lyrics.

\section{Person Deixis}

Person deixis designates the basic roles in a speech event, the speaker (first person), addressee or the person(s) spoken to (second person), and the person or persons who are neither speaker nor addressee (third person) (Cruse, 2000: 319). In this song of Back to you there are person deixis. It can be seen in this table:

Table 1. Number of Person Deixis

\begin{tabular}{|c|c|c|c|}
\hline \multirow[t]{2}{*}{ Song } & \multicolumn{3}{|c|}{ Personal deictic words } \\
\hline & First Person & Second Person & Third Person \\
\hline 1 Back To You & $\begin{array}{l}\text { I (17 data), We (3 } \\
\text { data), My (3 data), } \\
\text { Me (3 data) }\end{array}$ & You (13 data) & It (6 data) \\
\hline
\end{tabular}

From the table above, it can be seen the total of person deixis is 45 data from song of Back to you. The lyric which contain person deixis is "you could break my heart in two". There are 2 data person that lyric. First data is second person deixis you. You refers to the boy. The function of second person deixis you is as subject of singular pronoun. Second data is first person deixis $m y$. My is included as first person deixis. My refers to the singer Selena Gomez. My is first person deixis because it includes the speaker as singular possesive pronoun object. The lyric which contain third person deixis is "but when it heals, it beats for you".It referes to Selena's heart. The function of third person deixis is as object of singular pronoun. Based on the explanation above, the researcher notes that from Back to you song, the use of personal deixis that is followed by the three types of personal deixis occurs.

\section{Surakarta English and Literature Journal}


Vol.2. No.2 AUGUST 2019

The function of person deixis is to indicate the use of personal pronoun in the song lyrics.

2. Place Deixis

Spatial or place deictic word indicates location in space relative to the speaker

(Cruse, 2006:166). From the song of Back to you, the researcher found and classified the twelve songs which show the use of spatial or place deixis.

Table 2. Number of Place Deixis

\begin{tabular}{lcc}
\hline \multirow{2}{*}{ No. } & Song & \multicolumn{1}{c}{ Spatial or Place Deixis } \\
\cline { 3 - 3 } & & Distal Term \\
\hline 1. & Back To You & There (1 datum) \\
\hline
\end{tabular}

From the table above, it can be seen that in song Back To You there are 2 data of spatial or place deixis. The lyric which contain place deixis of distal term is there in lyrics "what was there was not sure". There refers to somewhere. The function of spatial deixis is to indicate the use of the distance or location in the song lyrics.

3. Time Deixis

Temporal or time deixis word indicates the timing of an event relative to the time of speaking (Cruse, 2006: 179; 2006: 321). From the song back to you, the researcher found and classified the song which shows that the temporal deixis or time deixis occurs. The researcher uses the table to make it easier and clearer.

Table 3. Number of Time Deixis

\begin{tabular}{llc}
\hline No. Song & Temporal or Time Deixis \\
\cline { 3 - 3 } & & Pure deictic word and specific time \\
\hline 1 & Back To You & Every time (1 datum), Cold evening (1 datum) \\
\hline
\end{tabular}

From the table above, the researcher found 2 data of time deixis. First data is every time in the lyric "every time we talk". Second data is cold evening in the lyric"thougt that I could you with acold evening". Every time and cold evening refers to time.Based on the explanation above, the researcher includes that from the song Back to you, the use of temporal deixis occurs. The function of temporal deixis is to indicate the use of the timing in the song lyrics.

After analyzing and determining the types of deixis and also interpreting the references meaning that are used in Back to you song lyric, the findings of frequency of deixis types which are used in the songs of Selena Gomez are presented as follows:

Table 4. Number of Types of Deixis

\begin{tabular}{lcc}
\hline No. & Types Of Deixis & Frequency \\
\hline 1. & PersonDeixis & 45 \\
\hline 2. & Place Deixis & 1 \\
\hline 3. & Time Deixis & 2 \\
\hline
\end{tabular}


Vol.2. No.2 AUGUST 2019

From the table above, it shows that the number or frequency of deixis which is taken from the song Back to youare person deixis, placedeixis and timedeixis appear in Back to yousong lyric. The most dominant types of deixis that are used in songs of Back to youare person deixis (45 data). Thus the dominant words of person deixis in Back to yousong Lyric use first person deixis which are $I, M e, M y, W e$.

\section{CONCLUSION}

Following the discussion above, finally the researcher concludes that the song lyrics of Back to you use all types of deixis which are person, place, and time deixis occurs in a song of Back to you. Personal deixis that is used includes three types of person deixis which are first person deixis, second person deixis and third person deixis. In addition, the other types which are timedeixis and placedeixis occur in a song of Back to you. Most of personal deixis in Back to yousong lyric refer to the speaker her self which are encoded by first singular person deixis like $I, M y$. While for first plural person deixis which are We mostly refer to the speaker

In this research, person deixis is the most dominant types in the songs. It is because the singer tells about the love feeling to the boy in her song that make the use of person deixis type are more often than others.

The researcher notes that by using the deixis it will make easily to describe the function of personal, pronoun, time, and demonstrative which are connecting the utterance with relation of person, space, and time. It also useful to catch the reference meaning that include who, where, and when the utterance isuttered.

\section{REFERENCES}

Blaxter, L., Hughes, C. and Tight, M. (2006). How to Research (3rd edition). Milton Keynes: Open University Press.

Cruse, A. (2006). A Glossary of Semantics and Pragmatics. Edinburgh: Edinburgh University Press.

Gazdar, G. (1979).Pragmatics: Implicature, Presupposition, and Logical Form. New York: Academic Press.

Griffiths, P. (2006). An Introduction to English Semantics and Pragmatics. Eidenburgh: Eidenburgh University Press.

Hasanah. (2006). The Use of Deixisin Gladiator Movie's Manuscript.Surakarta:Muhammadiyah Surakarta University

Hatch, E. (1992). Discourse and Language Education. Cambridge: Cambridge University Press.

Horn, L and Ward, G. (2006). The Handbook of Pragmatic. Swaiialun Strcet, Carlton. Victoria: Blackwell Publishing 
Vol.2. No.2 AUGUST 2019

Kadman, N. (2001). Formal Pragmatics. Journal of Pragmatics. (pp.749755).Interfacultary Research Institutes. Institute for Logic, Language and Computation.

Kreidler, C. W. (1998). Introducing English Semantics.New York: Routledge.

Levinson, C. S. (1983).Pragmatics. Cambridge: Cambridge University Press.

Lycan: (1995). Mental Content in Linguistics Form. Philosophical Stutied 58: 14754.

Lyons, J. (2002). Natural Language and Universal Grammar. London: Cambridge University Press.

Piragasam, G. A. (2013). Music Aprreciation and Self-actualization of Gifted Students: Procedia Social and Behavioral Sciences. (pp. 124-132). Malaysia: Kebangsaan Malaysia University.

Saeed, J.I. (2003). Semantics $2^{\text {nd }}$ Edition. London: Blackwell Publishing. . (1997). Semantics $3^{\text {rd }}$ Edition. London: Blackwell Publishing.

Santosa, R. (2012). Metode Penelitian Kualitatif Kebahasaan. Draf Buku. Surakarta: Fakultas Sastra dan Seni Rupa Universitas Sebelas Maret.

Walter, E. (2008). Cambridge Advanced Learner's Dictionary 3rd Edition. London: Cambridge University Press.

Wijaya, D. P and Rohmadi, M. (2011). Analisis Wacana Pragmatik Kajian Teori dan Analisis. Kadipiro Surakarta: Yuma Pustaka

Wulandari, S. (2008). The Use of Deictic Expression at Early Pre-Operational Stage Children. Semarang:Diponegoro University

Yule, G. (1996). Discourse Analysis. Cambridge: Cambridge University Press. 